\title{
Ensuring adequate capital investment in Canadian health care
}

\author{
Bijan Teja MD MBA, Imtiaz Daniel PhD MHSc, George H. Pink PhD, Adalsteinn Brown DPhil, David J. Klein MD MBA
}

Cite as: CMAJ 2020 June 22;192:E677-83. doi: 10.1503/cmaj.191126

C

oncerns over the sustainability of Canada's health care systems frequently lead to heated discussions about physician compensation, drug prices and wait times. In the current climate of an aging population, rising chronic disease and increasing demand for services, most discussions focus on operational funding; that is, the funding allocated annually to pay for doctors, drugs, hospital stays, or long-term and community care. Capital funding to support infrastructure is largely neglected in these discussions, yet inadequate or uncertain capital investment may threaten the sustainability and equity of the Canadian health care system even more than the questionable disbursement of operational funding.

Capital funding is what's used to build new facilities, redesign or restructure existing care operations and pay for new technologies. Unlike operational funding, which comes overwhelmingly from government, capital financing has more varied sources. These include gifts from corporations, foundations or individuals (philanthropy); debt (debentures, loans and bonds); social impact bonds and grants; and funds from government. Just as in other sectors, health care capital varies substantially, between jurisdictions and over years, being vulnerable to policy and politics (as government policies on health care capital have historically alternated between control and expansion), as well as economic cycles. ${ }^{1}$

We examine some of the reasons for vulnerability in health care capital financing in Canada, draw insights from other industries and jurisdictions, and discuss potential solutions that could improve both productive and allocative efficiency.

\section{What is the state of capital investment in Canadian health care?}

Capital spending is used by many industries to ensure ability to meet future demand. Many studies show that companies with thoughtful and active capital allocation outperform others, ${ }^{2,3}$ and management consultancies have observed that the best organizations make capital investment a priority, investing in productivity improvements through sustaining capital expenditures. ${ }^{4}$ However, the magnitude of capital funding for Canadian health care varies substantially over time and falls far below what many believe is necessary for an innovative and technologically up-to-date health care system. For example, conservative estimates from 2015 valued the cost of deferred maintenance in Canadian hospitals at about

\section{KEY POINTS}

- Unlike total health care spending in Canada, which has increased steadily over the past 20 years, capital investment (that supports infrastructure and technology) has both varied more and declined in recent years, suggesting underinvestment and inequity in health care capital.

- Canada's health system is particularly vulnerable to fluctuations in capital spending because the cycles for capital investment are longer than our political cycles.

- For the most part, use of capital instruments in Canada has not been innovative, and there are fewer studies on financing models in Canadian health care than in other countries.

- Canada needs greater expertise in capital investment and further research to increase regular use of innovative financial tools.

- In the years ahead, Canada should invest in improving Canadian health care capital funding, engaging new sets of investors and increasing our sophistication in capital planning and allocation.

\$15.4 billion (range $\$ 4-\$ 28$ billion). ${ }^{5}$ This figure does not include necessary investments in new health care facilities or technology.

Although some might assume fixed spending on health care and think that increasing capital investment in health care would require a corresponding reduction in spending on operations, in practice, capital funding can come from a wide range of sources and may not necessarily require a reduction in operating dollars. Furthermore, capital investment may increase efficiency and reduce operating costs. For example, caring for patients in modern hospitals and longterm care facilities can facilitate infection control (single rooms, isolation rooms, appropriate ventilation, etc.), and reduce overall health system costs previously attributable to spread of nosocomial pathogens or community-acquired infection in an outbreak. ${ }^{6}$

Canada's total health care capital funding has grown over the last 2 decades, from $\$ 2.3$ billion to $\$ 8.1$ billion annually in current Canadian dollars (Figure 1$),{ }^{7}$ yet health care capital investment as a percentage of gross domestic product remains lower than that of many Western Organisation for Economic Co-operation and Development countries, including the United States, New Zealand, Australia, France and Germany; it exceeds only a few comparator countries, such as the United Kingdom and Italy. ${ }^{8}$ Furthermore, unlike total health care spending in Canada, which has increased steadily over the past 20 years, health care capital 
investment has seen larger variability with a recent decline (Figure 1). The compound annual growth rate for total health care spending stayed relatively constant between 2007-2012 and 2012-2017 (5.7\% v. 4.2\%, respectively), while the rate for capital investment has declined substantially $(6.3 \%$ v. $-3.7 \%$, respectively). ${ }^{7}$ One possible interpretation is that Canadians are seeing diversion of capital funding to meet operating expenses (which amounts to compromising our future to fund our present).

A

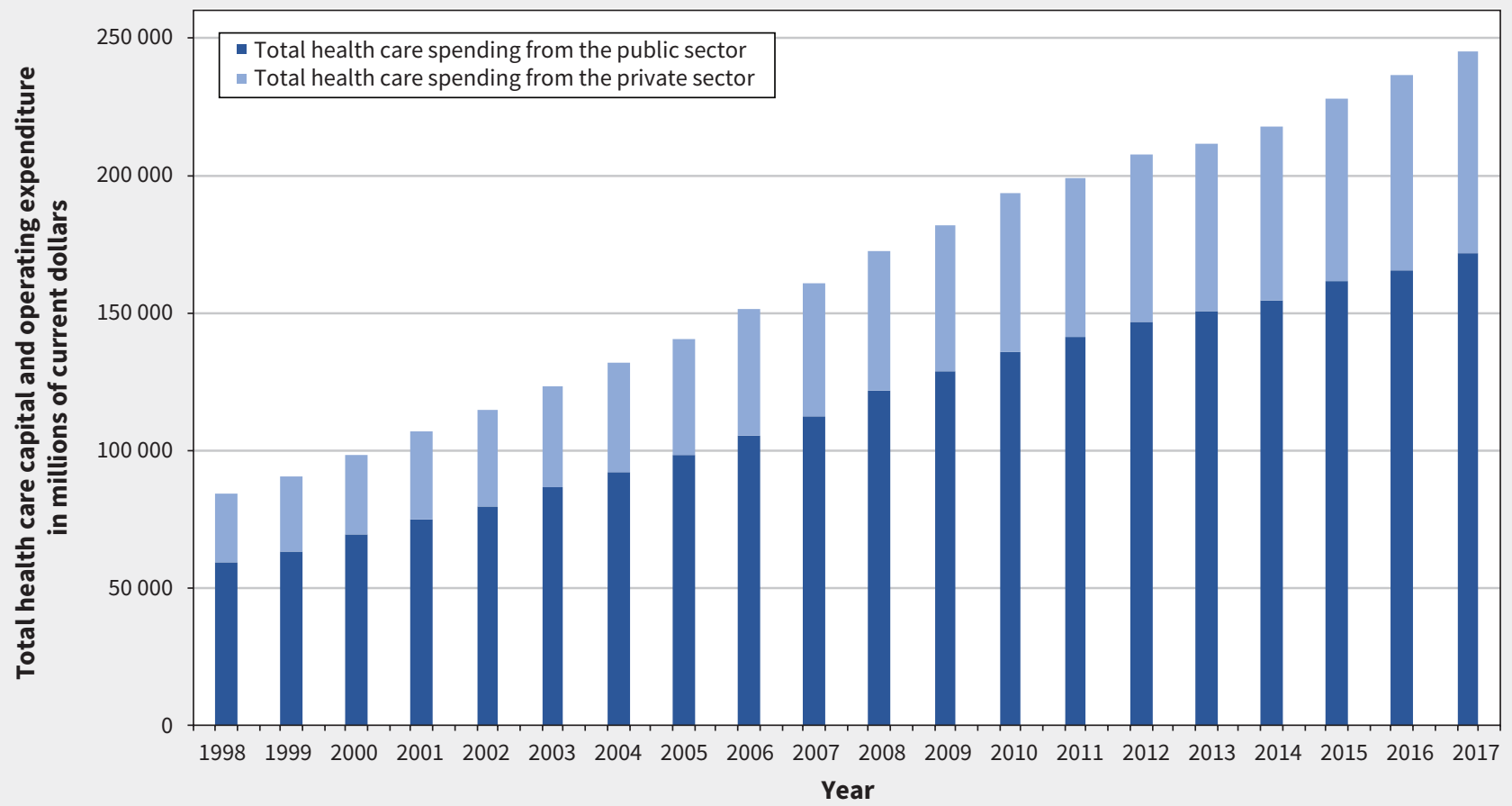

B

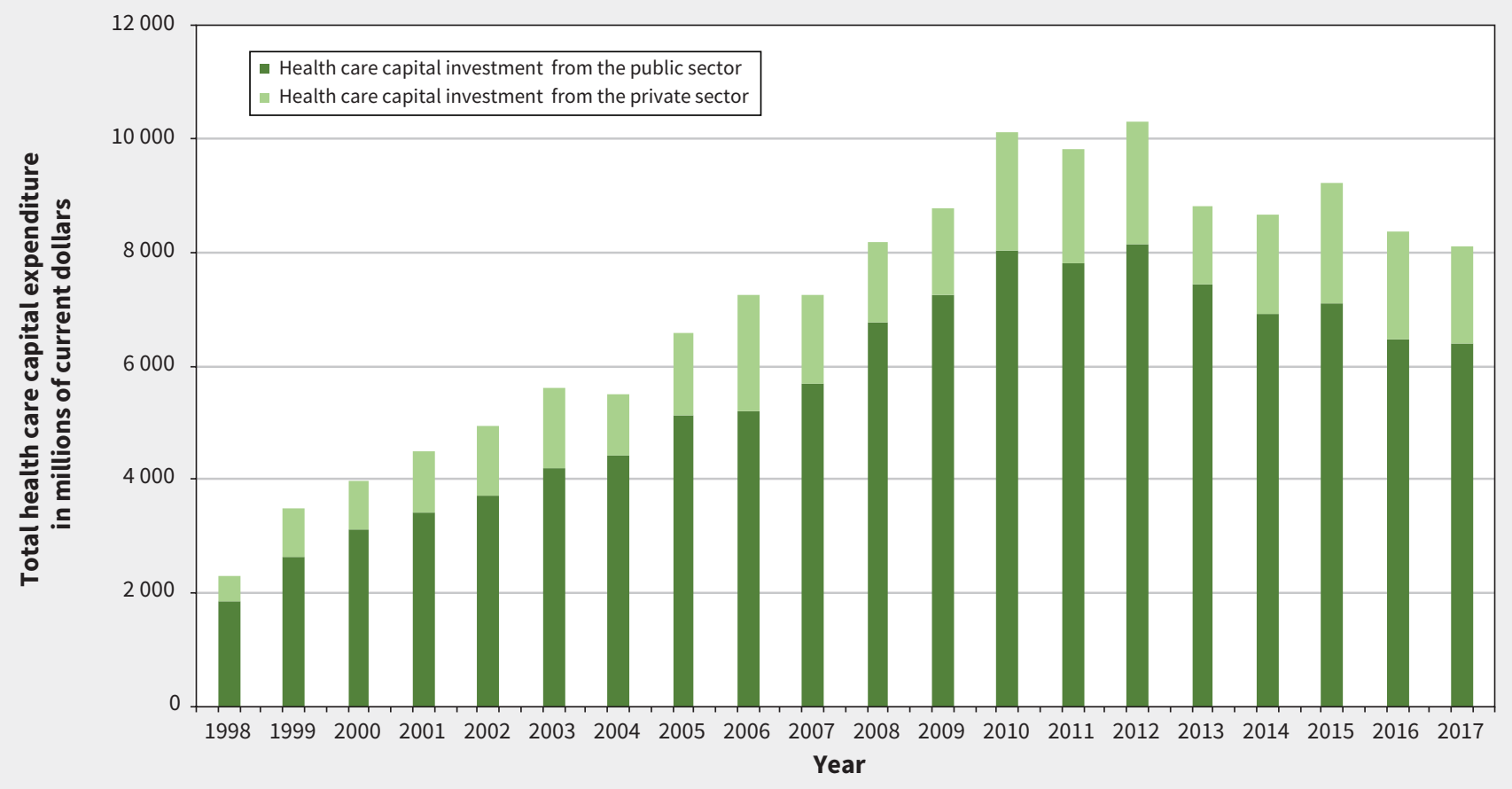

Figure 1: Trends in total health care spending (A) and health care capital investment (B) in Canada from 1998 to 2017. Data obtained from the Canadian Institute for Health Information, National Health Expenditure Database (2019).? 
Over the past 15 years, the Canadian health care system has seen large annual fluctuations in capital expenditure, in both the public and private sector (Figure 2). Although changes in total health care spending in Canada fluctuated relatively little between 2003 and 2017 (Figure 2A), there were large swings in health care capital investment in the public and private sector in Canada during the same period (Figure 2B). ${ }^{7}$

\section{Why is capital funding so variable?}

\section{Economic cycles}

Like operational funding, the source of most capital funding is tax revenue, which varies with the overall economic health of each province and of the country as a whole. There is also a strong link between stock market performance and philanthropy. ${ }^{9}$

A

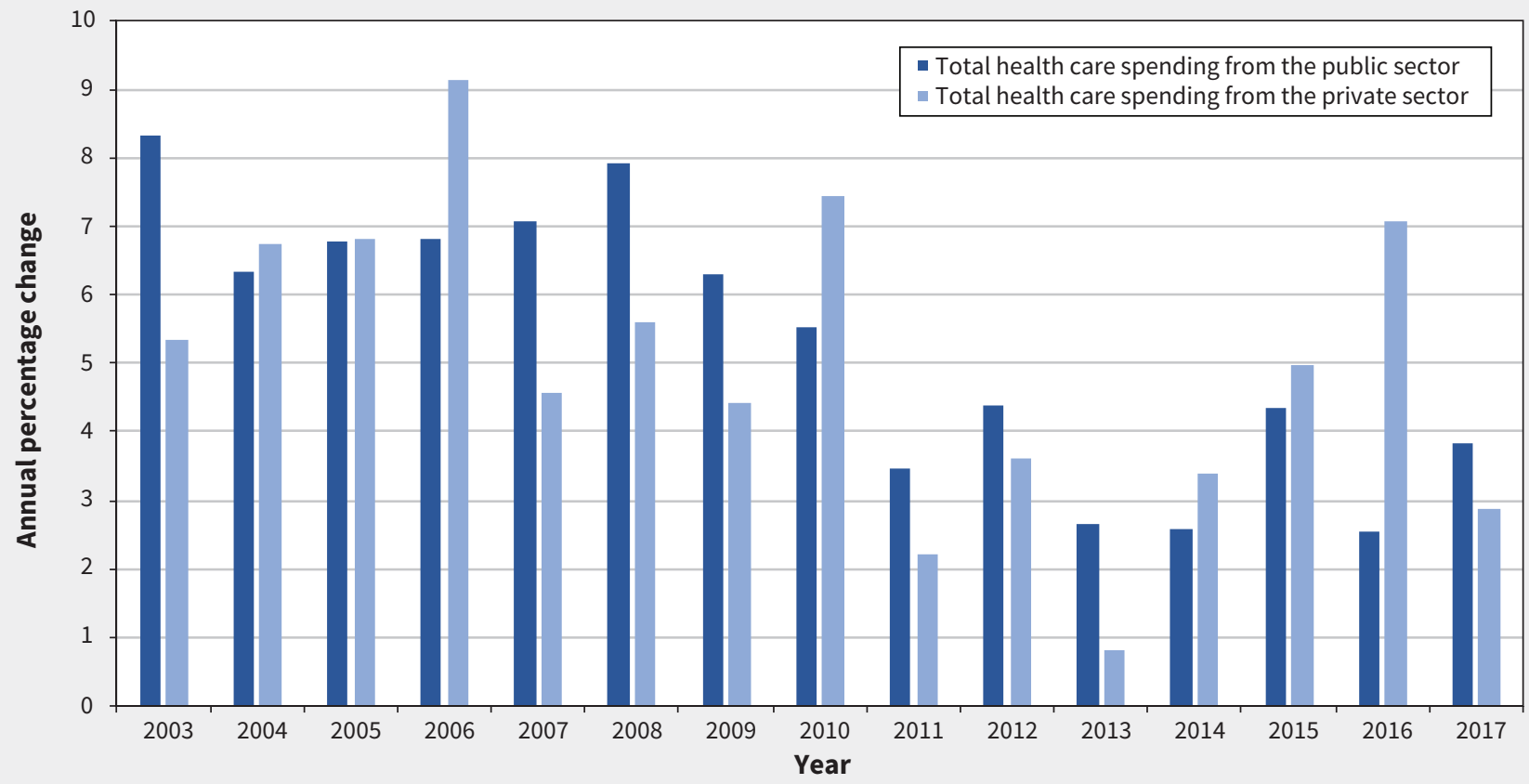

B

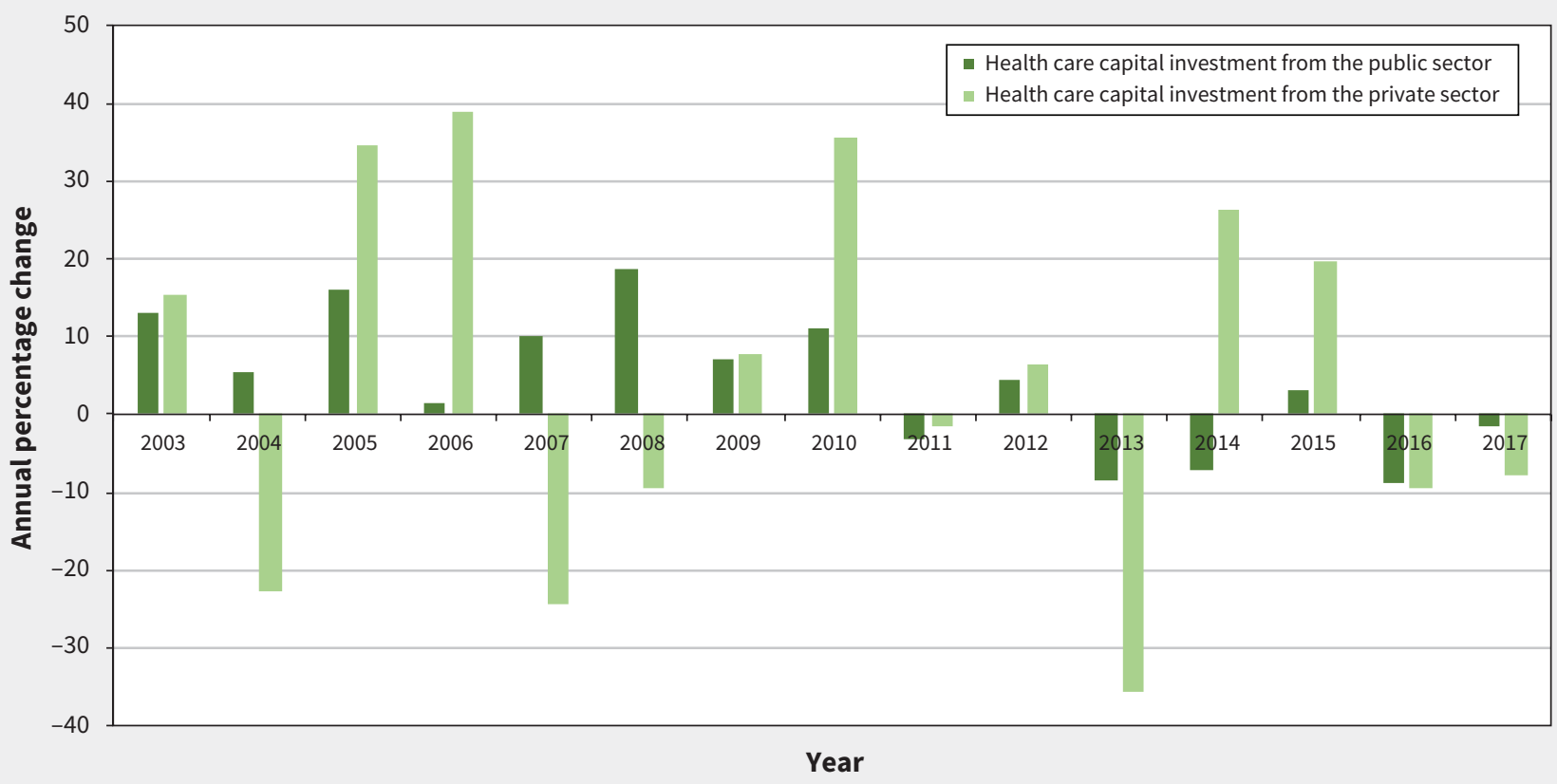

Figure 2: Annual percentage change in health care spending (A) and capital investment (B) in Canada between 2003 and 2017. Data obtained from the Canadian Institute for Health Information, National Health Expenditure Database (2019). ${ }^{\text {? }}$ 


\section{Credit ratings and interest rates}

The credit ratings of some provinces, such as Manitoba and Ontario, have recently been downgraded. ${ }^{10}$ This usually results in a higher rate of interest on loans, effectively increasing the cost of capital investment. This problem will only get worse if provinces face increases in interest rates or changes in their creditworthiness, and may be influenced by the recent effect of the coronavirus disease 19 (COVID-19) pandemic on the economy.

\section{Unevenness of charitable giving}

Philanthropy is an important source of funding that can sometimes bridge a funding gap for specific projects. However, philanthropy tends to be distributed unevenly among hospitals and may not be concentrated where infrastructure upgrades are most needed. For example, in downtown Toronto, the Princess Margaret Cancer Foundation, the Toronto General \& Western Hospital Foundation and the SickKids Foundation each raise more than $\$ 100$ million per year through donations and charitable activity, which is used for a variety of purposes, including updating and expanding facilities such as emergency departments and patient wards. ${ }^{11-13}$ However, smaller hospitals - such as Collingwood General and Marine Hospital, just a 2-hour drive north of Toronto - may have more difficulty raising capital through philanthropy. Collingwood General and Marine Hospital's recent campaign to secure $\$ 1.5$ million in financing over 12 to 16 months allowed it to upgrade surgical equipment, including a 15 -year-old fracture table that was missing pieces. ${ }^{14}$ Although some differences in funding would be understandable owing to difference in size and populations served, the imbalances in funding are more substantial than would be expected.

\section{Priorities and political cycles}

The decision horizon of many politicians is the time until the next election, which can sometimes lead to the deferral of substantial capital investments to future electoral cycles in order to avoid an increase in deficits in the current electoral cycle or in hope of greater future tax revenue. Capital investment, however, requires long-term planning and commitment, with time horizons of 20 years and longer.

\section{Why is erratic and insufficient capital funding a problem?}

As health systems develop, buildings and equipment age, new technology emerges and sites of care change. Insufficient capital can impair provision of the accepted or emerging standard of care to patients, especially when new, expensive technology for diagnosis and treatment becomes standard care. Furthermore, dilapidated buildings, malfunctioning equipment and closed facilities - with resultant increased distance that patients must travel to receive adequate care - can reduce equitable access to health care, ${ }^{15,16}$ which undermines a key principle of the Canada Health Act.

Innovation in health care may be inhibited if capital assets cannot fund research and development, new technology or improvements in care processes. Health care learners also benefit from the opportunity to learn using up-to-date technology. Fur- thermore, it is more difficult to recruit clinicians, scientists and other professionals to work in systems that lack up-to-date equipment and facilities because of lack of capital investment. ${ }^{17,18}$

Insufficient capital funding may also contribute to Canadian hospitals' overcrowding problem. Among 27 OECD countries, Canada's acute care-bed occupancy rate of $91.6 \%$ (2000 to 2015) was exceeded only by Israel and Ireland, and was far higher than the average occupancy rate in OECD countries of $75.7 \% .{ }^{19}$ In Ontario, which has faced capital challenges in the health system for many years, ${ }^{20,21}$ about half of hospitals have occupancy rates exceeding $100 \%$, with some rates as high as $140 \%$, which is well above what is generally considered safe (85\%). ${ }^{20}$

In health care, investment in facilities and technologies has been linked to improvements in quality of care..$^{22}$ Literature from the US suggests that health systems with greater availability of financial resources and increased likelihood of making capital investments are more likely to adopt innovations, leading to some improvements in quality of care. ${ }^{9,22-24} \mathrm{~A}$ Canadian study from 2003 found that increased total spending was linked to increased patient satisfaction, ${ }^{25}$ but the association between capital and performance noted in US studies ${ }^{22}$ has not been examined rigorously in the Canadian context.

Thoughtful decision-making on capital is complicated by the politicized nature of decision-making when capital financing is subject to ministerial approval. One of the biggest challenges faced by corporations, including health care institutions, is setting clear investment objectives that can be compared across alternative investments. In most industries, competing capital projects are evaluated using return-on-investment methods such as net present value and internal rate of return. The methods require estimation of expected cash flows, which lays bare assumptions being made about the projects, exposing optimistic forecasts and other telltale traits of pet projects and personal bias. ${ }^{4}$ When the focus is not on return on investment but rather on opening a building or political impact, then decision-making becomes more ad hoc and variable in outcome. These factors can play out in challenging ways, as seen in the case of the Greater Toronto Area (Box 1). ${ }^{26,27}$

Box 1: Unsatisfactory capital funding in the Greater Toronto Area

Two reports by PriceWaterhouseCoopers found that spending for hospital services in the area surrounding Toronto lagged behind other areas in Ontario by as much as $\$ 944.5$ million per year between 2002 and $2007 .{ }^{26}$ For about 10 years, planners knew that the Greater Toronto Area would grow substantially in size, with the suburban city of Mississauga being the nation's fifth-largest city. This meant that new hospital construction should have been planned to accommodate this suburban growth, but instead the concentration of projects and funding moved elsewhere, essentially to where current populations (and voters) were rather than where they would be and where bed capacity would be needed. ${ }^{26}$

Underinvestment over time continues to have ramifications today, with hospitals in Mississauga and other parts of the Greater Toronto Area continuing to face challenges with hallway medicine while frequently operating over $100 \%$ capacity. ${ }^{20,27}$ 


\section{How can capital financing in Canada be improved?}

Canada's system of raising capital for health care is, for the most part, no different than it was 100 years ago, with taxation and charitable giving providing most funding. However, it is unlikely that Canada can bridge its funding gap with tax dollars and charitable giving alone. Canadian health care leaders, like those in other countries, need to develop smarter ways to access and deploy capital, as capital investment is an area of need.

\section{Innovative funding through public-private partnerships}

Experimentation with innovative capital funding through partnerships has worked well in some cases and poorly in others. It can be difficult to achieve good oversight of capital investment in health care for several reasons, including difficulty measuring return on investment, the need to please stakeholders with diverse interests and the frequent use of health care spending as a political tool in electoral cycles, ${ }^{28}$ whereby the desire of governments or politicians to please voters in certain regions may take priority over addressing projected future demands.

One example of funding innovation in Canada is the Centre hospitalier de l'Université de Montréal (CHUM). A modernization program was launched to merge all CHUM activities in 1 location by 2020 . This was the largest public-private hospital venture in Canada's history. The project was built using a public-private partnership model (commonly referred to as a P3 model), whereby the Government of Quebec selected a private consortium to build, own and operate the facility for 30 years, with the government paying rent for that period. Such models enable the government to retain some control over the project and uphold the public mission while leveraging private sector expertise to complete the project efficiently and identify ways to reduce costs.

The private consortium developed an innovative proposal that provided $85 \%$ of clinical services during the first phase (as opposed to $55 \%$, as originally anticipated by CHUM), which unlocked a better financing solution and substantial savings for the government. ${ }^{29}$ It is estimated that this P3 saved about $\$ 376$ million. ${ }^{29}$ The first phase of the project was completed - albeit behind schedule and with unanticipated additional costs - in 2017.

The public-private partnership model is not an easy solution to the capital funding gap. Some P3 projects in Canada have shown good outcomes but others have resulted in major construction delays and resource waste. For example, in 2015, Ernst and Young estimated cost savings for the St. Michael's Hospital Redevelopment Project - in which a province-owned corporation hired a consortium to design, build and finance St. Michael's expansion and redevelopment - at $20.7 \%$, or $\$ 91.5$ million; ${ }^{30}$ however, as of March 2020, construction has been stalled for several months while a member of the consortium faces a series of lawsuits related to its problems completing major public-sector construction projects. ${ }^{31}$ Similar delays have arisen at Cambridge Memorial Hospital, ${ }^{32}$ which hired the same corporation; this highlights the importance of due diligence and careful selection of partners to be sure that capital can be used effectively and according to plan.
Because health care infrastructure projects are often large and resource intensive, competition may be limited to only a few large partner organizations. ${ }^{33}$ This means P3 models can result in near monopolies. P3 partnerships in Canada have also suffered from substantial administrative demands in managing relationships between several parties over extended periods of time. ${ }^{34}$ To reap the benefits of P3 models while avoiding pitfalls will require learning from previous projects and similar innovative funding in other jurisdictions.

The use of P3s is often seen as an effective way to speed up and increase access to capital. However, there is some debate about the effectiveness of these models. Australia has been noted as a jurisdiction with published best practice guidelines on P3s, where the government recommends consideration of a P3 for any project with a capital cost in excess of AUD\$50 million (about Can\$45.3 million). ${ }^{35}$ Canada is described as having one of the most efficient P3 procurement processes. ${ }^{36}$ The UK has been cited as a jurisdiction in which P3s are an inefficient use of government sources. ${ }^{37,38} \mathrm{How}$ ever, P3s comprise just one method of accessing capital and come with substantial risks, as seen in the case of St. Michael's Hospital. Other ways of accessing capital include bonds and debentures. There are relatively few data comparing these financing models, particularly in Canada. ${ }^{9}$ Public-private partnerships, bonds and other financing vehicles merit further study.

\section{Better tools for decision-making}

Tools are available that can help Canadian health care leaders be more effective in capital decision-making, but ensuring a focus on outcomes and the actual use of these tools will require greater expertise in efficient capital allocation and a shift in policy toward maximizing return on investment. For example, in Mississippi, standardized 1-page project evaluation reports with pro forma projections, anticipated return and project disclaimers indicating potential risks and assumptions - were implemented to simplify the review, comparison and evaluation of potential capital investment projects. This tool has strengthened decision-makers' ability to select projects that align with the region's objectives in terms of impact, timing, rationale and risks, and has helped to ensure that capital is allocated efficiently in projects that are fit for purpose. ${ }^{39}$ Interviews with Canadian health care decision-makers identified a number of examples of health care organizations using different tools to plan and manage capital expenditure; however, the use of these tools did not spread across organizations, or even persist over time within one organization. ${ }^{9}$ Sharing these tools for capital investment decisions across organizations in Canada and enhancing them over time through outcomes measurement and collaborative research would be opportune. ${ }^{9}$

\section{Leverage strategic partnerships and learn from the experience of the private sector}

Because capital investment is so challenging, many organizations compensate by finding strategic investors; that is, investors who can provide not only capital but also experience and expertise on how to invest that capital wisely. There are several potential strategic investors in Canada with deep experience in capital 
management and infrastructure investing, such as the Canada Pension Plan, Ontario Municipal Employees Retirement System and private entities. As an example, the Ontario Municipal Employees Retirement System is a major capital investor, in Canada and abroad, in hospital systems, long-term care facilities and laboratory infrastructure. ${ }^{40}$ Given that the missions of these funds are closely tied to the well-being of older Canadians, they could be valuable resources and partners for leaders who are making decisions about health care capital investment in Canada.

\section{Community involvement}

To ensure that capital investment projects align with the needs of those they are intended to benefit, it's important to engage community stakeholders, to be transparent with respect to the business case and to choose project outcomes that are relevant to communities and can be measured over the long term. Increased transparency is key to effective community involvement. Deliberative community engagement - that is, involving the community in discussion and deliberation about issues, ideally leading to concrete proposals that can be adopted by policy-makers - can be implemented successfully. ${ }^{41}$ Seeking the views of informed experts alongside the general community, and putting extensive effort into ensuring that community participants are well informed before the deliberation are key to success. ${ }^{41}$ It's also important to evaluate such community engagement programs. ${ }^{42}$

\section{More favourable tax treatment for charitable giving} Charitable giving is reduced during recessions because of decreased disposable income; charitable giving is also affected by tax policy. ${ }^{43} \mathrm{~A} 2002$ review found that tax reform can have a long-lasting influence on charitable giving. ${ }^{44}$ For example, a new policy that makes it more favourable for moderate-income earners to give may positively influence their giving habits even when they enter a higher income tax bracket. ${ }^{44}$ Although charitable giving can lead to allocative inefficiencies, tax and other incentives should be leveraged to grow contributions from this sector for the purpose of bridging the capital financing gap that has grown over the past several years. ${ }^{45}$ For example, an inequity in the current tax system sees donation of real estate or private company shares taxed more heavily than gifts of publicly traded shares. ${ }^{46}$ This inequity applies to many of the 110000 members of the Canadian Federation of Independent Business, who are all private businesses with an opportunity to give back to the communities that played an important role in their success. ${ }^{47}$ Removing the capital gains tax on donation of real estate or private company shares could stimulate a substantial increase in charitable giving among Canadians, including to charitable organizations raising money for health care capital expenditures.

\section{Conclusion}

Despite increases in total health care spending in Canada, capital investment in Canadian health care has seen a substantial decline in recent years, contributing to Canada's high hospital occupancy rates, hallway health care problem and operating inefficiencies. ${ }^{5,7}$
More capital alone will not solve the problem. Capital investment must also be overseen and managed by expert leadership, fairly, transparently and ethically, to protect the public's interest and trust. The challenges underpinning the current level and effectiveness of our health care system will not be solved with one method alone. Moreover, there is a dearth of research on this topic, despite its importance in maintaining the performance of the Canadian health care system. Provinces should guide organizations in investigating and evaluating innovative funding models and should consider partnering more frequently with agencies that have expertise in capital funding. Definitions of governance competencies should include expertise in capital planning and management. Stronger, forward-looking capacityplanning tools may help guide smart decisions about capital. Finally, the tax treatment for charitable giving deserves further consideration, particularly as Canada faces a likely stock market decline triggered by the COVID-19 pandemic, and other factors.

\section{References}

1. Dubois E. Political business cycles 40 years after Nordhaus. Public Choice 2016; 166:235-59. doi: 10.1007/s11127-016-0313-z.

2. Hall S, Lovallo D, Musters R. How to put your money where your strategy is. New York: McKinsey \& Company; 2012. Available: www.mckinsey.com/business -functions/strategy-and-corporate-finance/our-insights/how-to-put-your-money -where-your-strategy-is (accessed 2019 Mar. 17).

3. Thorndike WN Jr. The outsiders: eight unconventional CEOS and their radically rational blueprint for success. Brighton (MA): Harvard Business Review; 2012.

4. Banholzer M, Chandarana A, Straden D. Nine practices for better capitalinvestment management. New York McKinsey \& Company; 2017. Available: www.mckinsey.com/industries/capital-projects-and-infrastructure/our-insights /nine-practices-for-better-capital-investment-management (accessed 2019 Mar. 16).

5. Roberts G, Samuelson C. Deferred hospital maintenance in Canada: there is more to 'a building' than building it. Ottawa. HealthCareCan; 2015.

6. Lateef F. Hospital design for better infection control. J Emerg Trauma Shock 2009;2:175-9.

7. National Health Expenditure Trends, 1975 to 2019. Ottawa: Canadian Institute for Health Information; 2019.

8. OECD. Capital expenditure in the health sector. In: Health at a Glance 2015: OECD Indicators. Paris: OECD (Organisation for Economic Co-operation and Development) Publishing; 2015.

9. Klein DJ, Brown AD, Huynh TM, et al. Capital spending in healthcare: a missed opportunity for improvement? Ottawa: Canadian Foundation for Healthcare Improvement; 2013.

10. Moody's [main page]. Available: www.moodys.com (accessed 2019 July 21).

11. Summaries: fiscal 2019. Toronto: Princess Margaret Cancer Foundation. Available: https://thepmcf.ca/getattachment/653ef40f-8887-4933-b5b1-98a187b8ba42 /2019-PMCF-Financial-Fiscal-Summary.aspx (accessed 2020 Mar. 14).

12. A healthier world starts with ...: 2018/19 report to our donors. Toronto: Toronto General \& Western Hospital Foundation. Available: https://tgwhf.ca/about-us/ publications/2018-19-report-to-our-donors/ (accessed March 14, 2020).

13. Annual report 2018-19: a new SickKids will rise - A vision for the future. Toronto: SickKids Foundation; 2019. Available: http://web.sickkidsfoundation. com/annual-report-2018/ (accessed 2020 Mar. 14).

14. Adams I. Collingwood hospital launches fundraising campaign for surgical equipment. Simcoe.com; 2016. Available: www.simcoe.com/news-story/7019970 -collingwood-hospital-launches-fundraising-campaign-for-surgical-equipment/ (accessed 2019 July 8).

15. Hameed SM, Schuurman N, Razek T, et al.; Research Committee of the Trauma Association of Canada. Access to trauma systems in Canada. J Trauma 2010;69: 1350-61. 
16. Benchimol El, Kuenzig ME, Bernstein CN, et al.; Canadian Gastro-Intestinal Epidemiology Consortium. Rural and urban disparities in the care of Canadian patients with inflammatory bowel disease: a population-based study. Clin Epidemiol 2018;10:1613-26.

17. Jones GI, Alford KA, Russell UJ, et al. Removing the roadblocks to medical and health student training in rural hospitals in Victoria. Aust J Rural Health 2003;11: 218-23.

18. Viscomi M, Larkins S, Gupta TS. Recruitment and retention of general practitioners in rural Canada and Australia: a review of the literature. Can J Rural Med 2013;18:13-23.

19. OECD. Health care activities. In: Health at a Glance 2017: OECD Indicators. Paris: OECD (Organisation for Economic Co-operation and Development) Publishing; 2017.

20. A sector on the brink: the case for a significant investment in Ontario's hospitals: pre-budget submission - 2018 Ontario budget. Toronto: Ontario Hospital Association; 2018

21. Working capital and Ontario hospitals. Toronto: Ontario Hospital Association; 2005.

22. Levitt SW. Quality of care and investment in property, plant, and equipment in hospitals. Health Serv Res 1994;28:713-27.

23. Nystrom PC, Ramamurthy K, Wilson AL. Organizational context, climate and innovativeness: adoption of imaging technology. J Eng Technol Manage 2002;19:221-47. doi: 10.1016/S0923-4748(02)00019-X.

24. Encinosa WE, Bernard DM. Hospital finances and patient safety outcomes. Inquiry 2005;42:60-72.

25. Pink GH, Murray MA, McKillop I. Hospital efficiency and patient satisfaction. Health Serv Manage Res 2003;16:24-38.

26. Assessing the gap in health and social service funding between the GTA/905 and the rest of Ontario: an Update. London (UK): PriceWaterhouseCoopers; 2007.

27. Ontarians tell their hallway medicine stories. CBC News 2020 Jan. 30. Available: www.cbc.ca/news/canada/toronto/ontario-hallway-medicine-hospital -overcrowding-patients-1.5443172 (accessed 2020 Mar. 14).

28. Health care continues to be top issue for Canadians (37\%); climate change climbs to second $(30 \%,+4)$, ahead of affordability $(26 \%,-2)$. Toronto: Ipsos; 2019. Available: www.ipsos.com/en-ca/news-polls/Health-Care-Continues-to-Be -Top-Issue-for-Canadians (accessed 2020 Mar. 14).

29. Centre hospitalier de l'Université de Montréal. Toronto: The Canadian Council for Public-Private Partnerships; 2013.

30. Value for money assessment: St. Michael's Hospital Redevelopment Project. Toronto: Infrastructure Ontario; 2015. www.infrastructureontario.ca/workarea /downloadasset.aspx?id=34359739123 (2015, accessed April 5, 2019). Login required to access content.

31. McFarland J, Strauss M. Bondfield Construction applies for credictor protection in Ontario. Globe and Mail [Toronto]. Available: www.theglobeandmail.com/ business/article-bondfield-construction-applies-for-creditor-protection/ (accessed 2019 Apr. 5).
32. Gaskin P. Open letter to the community from Patrick Gaskin, President and CEO. Cambridge (ON): Cambridge Memorial Hospital; 2018. Available: www.cmh.org/news /open-letter-community-patrick-gaskin-president-and-ceo (accessed 2019 Apr. 5).

33. Competition issues in public-private partnerships. Paris: Organisation for Economic Co-operation and Development. Available: www.oecd.org/competition/ competitionissuesinpublic-privatepartnerships.htm (accessed 2019 Dec. 11).

34. Barlow J, Roehrich J, Wright S. Europe sees mixed results from public-private partnerships for building and managing health care facilities and services. Health Aff (Millwood) 2013;32:146-54.

35. National Public Private Partnership: policy framework. Canberra (Australia): Australian Government, Department of Infrastructure and Regional Development; 2016.

36. Service Works Global/Canadian Council for Public-Private Partnerships. Publicprivate partnerships - What the world can learn from Canada. Toronto: The Canadian Council for Public-Private Partnerships; 2015.

37. Santandrea M, Bailey S, Giorgino M. Value for money in UK healthcare publicprivate partnerships: a fragility perspective. Public Policy and Administration 2016;31:260-79. doi: 10.1177/0952076715618003.

38. Holmes J, Capper G, Hudson G. Public private partnerships in the provision of health care premises in the UK. Int J Proj Manag 2006;24:566-72. doi: 10.1016/j.ijproman 2006.07.004.

39. Christensen S, Mallia J. Change for the delta: a process for strategic planning in a challenging market: a Mississippi hospital is helping maintain its financial viability with a long-range strategy. Healthc Financ Manage 2018;72:54-9.

40. Our portfolio. OMERS (Ontario Municipal Employees Retirement System) Infrastructure. Available: www.omersinfrastructure.com/Investments (accessed 2020 Mar. 15).

41. Gregory J, Hartz-Karp J, Watson R. Using deliberative techniques to engage the community in policy development. Aust New Zealand Health Policy 2008;5:16.

42. Abelson J, Montesanti S, Li K, et al. Effective strategies for interactive public engagement in the development of healthcare policies and programs: a research project commissioned by the Canadian Health Services Research Foundation and the New Brunswick Health Research Foundation. Ottawa: Canadian Health Services Research Foundation; 2010.

43. Bakija JM. Tax policy and philanthropy: a primer on the empirical evidence for the U.S. and its implications. Soc Res (New York) 2013;80:557-84.

44. Auten GE, Sieg H, Clotfelter CT. Charitable giving, income, and taxes: an analysis of panel data. Am Econ Rev 2002;92:371-82.

45. Special Senate Committee on the Charitable Sector. Catalyst for change: $a$ roadmap to a stronger charitable sector. Ottawa: Senate of Canada; 2019.

46. Toronto General \& Western Hospital Foundation. How the 2019 Budget can help all charities in Toronto and the GTA: removing the capital gains tax on gifts of private company shares and real estate. Toronto Star 2018 Oct. 10.

47. Johnson DK. Why Trudeau government should consider tax changes for charities when putting together the 2019 budget. Globe and Mail [Toronto]. Available: www. theglobeandmail.com/business/commentary/article-why-trudeau-government -should-consider-tax-changes-for-charities-when/ (accessed 2020 Mar. 15).

\begin{abstract}
Competing interests: David Klein reports serving as a consultant for Imperial Capital since 2007 and Searchlight Capital since 2019. In these roles, Dr. Klein assists in the identification of health care investments, due diligence and in board roles. Currently he is not involved in any active health care investments for these funds in Canada or the United States. In addition, he has been appointed to the Health Sector Audit Board for the Province of Ontario. No other competing interests were declared.
\end{abstract}

This article has been peer reviewed.

Affiliations: Institute of Health Policy, Management and Evaluation (Teja, Daniel, Pink, Brown), Interdepartmental Division of Critical Care Medicine (Teja), University of Toronto; Ontario Hospital Association (Daniel), Toronto, Ont.; Department of Health Policy and Management (Pink), Gillings School of Global Public Health, University of North Carolina, Chapel Hill, NC; Dalla Lana School of Public Health (Brown, Klein); Department of Critical Care, St. Michael's Hospital (Klein), Toronto, Ont.
Contributors: Imtiaz Daniel, David Klein, George Pink and Adalsteinn Brown contributed to the conception and design of the work. Bijan Teja and Adalsteinn Brown drafted the manuscript. All of the authors revised it critically for important intellectual content, gave final approval of the version to be published and agreed to be accountable for all aspects of the work.

\section{Correspondence to: David Klein,} kleind@smh.ca. 